Berlian Nurtyashesti Kusumadewi, Novy H.C. Daulima, Ice Yulia. W

Efektifitas Terapi Kognitif, Psikoedukasi Keluarga Dan Terapi Kelompok Suportif Pada Klien Dengan Ketidakberdayaan Melalui Pendekatan Model Transisional Meleis

\title{
Efektifitas Terapi Kognitif, Psikoedukasi Keluarga Dan Terapi Kelompok Suportif Pada Klien Dengan Ketidakberdayaan Melalui Pendekatan Model Transisional Meleis
}

\author{
Berlian Nurtyashesti Kusumadewi ${ }^{1}$, Novy H.C. Daulima ${ }^{2}$, Ice Yulia. $\mathbf{W}^{3}$ \\ ${ }^{1)}$ Akademi Keperawatan Ngesti Waluyo Parakan \\ ${ }^{2)}$ Fakultas Ilmu Keperawatan Universitas Indonesia
}

Korespondensi penulis: berlian.kusumadewi87@gmail.com

\begin{abstract}
Abstrak
Gangguan mental emosional dapat terjadi pada individu yang mengalami kondisi kesehatan yang kronis. Pasien yang sedang menjalani pengobatan medis ditemukan $25 \%$ diantaranya mengalami depresi dengan berbagai variasinya. Proses penyakit yang melemahkan juga merupakan hal yang berperan menyebabkan ketidakberdayaan klien dengan penyakit kronis. Ketidakberdayaan dan gejala depresi menunjukkan hubungan yang signifikan dan positif dengan ide untuk bunuh diri. Hasil pemberian tindakan keperawatan ners, terapi kognitif, psikoedukasi keluarga dan terapi suportif dapat menurunkan tanda gejala dan meningkatkan kemampuan klien penyakit kronis dengan ketidakberdayaan beserta keluarganya. Perlunya optimalisasi dan pengembangan pelayanan kesehatan jiwa kepada klien dengan masalah psikososial terkhusus klien dengan ketidakberdayaan di tatanan pelayanan puskesmas.
\end{abstract}

Kata kunci: penyakit kronis; pelaku rawat; dukungan keluarga; dukungan sosial; depresi

\section{PENDAHULUAN}

\section{Beberapa}

penelitian

memaparkan bahwa penyakit fisik umumnya menimbulkan gangguan mental emosional seperti depresi dan ansietas (Matcham, Rayner, Steer \& Hotopf, 2013; Mitchell et al, 2011; Reijinders, Ehrt, Weber, Aarslag \& Leentjens, 2008). Gangguan mental emosional dapat terjadi pada individu yang mengalami kondisi kesehatan yang kronis. Pasien yang sedang menjalani pengobatan medis ditemukan $25 \%$ diantaranya mengalami depresi dengan berbagai variasinya. Prevelensi depresi tinggi pada penyakit-penyakit kronis seperti penyakit arteri koroner (18-23\%), infark miokard 25\%, stroke 37,8\%, diabetes mellitus 9-27\%, penyakit parkinson 2-51\%, HIV/AIDS 4-18\%, kanker 6-25 \% dan epilepsi 40-60\% (Surkesnas Depkes, 2009). Mental Health Action Plan WHO (2013-2020) juga mengugkapkan jika miokard infark dan diabetes mellitus merupakan penyakit fisik kronis yang menjadi predisposisi terjadinya depresi. WHO pada tahun 2012 melaporkan bahwa depresi mempengaruhi 350 juta orang di seluruh dunia dan sekitar 1 juta orang bunuh diri setiap tahun yang sebagian besar disebabkan oleh depresi yang tidak diketahui dan tidak terobati.

Klien yang menderita penyakit kronis memicu terjadinya stres bagi klien. Klien yang menderita penyakit kronis cenderung memiliki tingkat kecemasan tinggi dan cenderung mengembangkan perasaaan ketidakberdayaan dan keputusasaan karena berbagai macam pengobatan yang tidak dapat menyembuhkan penyakit kronis yang dialami (Sarafino, 2006). Masalah lain yang dialami oleh klien yaitu kehilangan pekerjaan yang berpengaruh terhadap 
Berlian Nurtyashesti Kusumadewi, Novy H.C. Daulima, Ice Yulia. W

Efektifitas Terapi Kognitif, Psikoedukasi Keluarga Dan Terapi Kelompok Suportif Pada Klien Dengan Ketidakberdayaan Melalui Pendekatan Model Transisional Meleis

berkurangnya penghasilan klien padahal biaya pengobatan klien meningkat (Sarafino, 2006).

Ketidakberdayaan

yang

diakibatkan oleh penyakit kronik terjadi karena faktor fisiologis (gejala penyakit dan gejala penyerta), manajemen pengobatan, proses kehilangan, kurangnya pengetahuan, sistem perawatan kesehatan, stigma terhadap penyakit yang diderita, kurangnya sumber-sumber diluar individu, ketidakpastian dan pandangan budaya terhadap penyakit yang diderita (Lubkin \& Larsen, 2013). Proses penyakit yang melemahkan juga merupakan hal yang berperan menyebabkan ketidakberdayaan klien dengan penyakit kronis (Carpenito, 2010).

Individu yang menderita penyakit kronis dan mengalami ketidakberdayaan tersebut ada yang tidak menjalani perawatan di rumah sakit dan hanya menjalani perawatan di rumah dengan mengkonsumsi obat yang diberikan oleh dokter. Maka disinilah keperawatan kesehatan jiwa komunitas berperan. Keperawatan kesehatan jiwa komunitas adalah pelayanan keperawatan yang komprehensif, holistik, dan paripurna yang berfokus pada masyarakat yang sehat jiwa, rentan terhadap stress (resiko gangguan jiwa) dan dalam tahap pemulihan serta pencegahan kekambuhan (gangguan jiwa) (Stuart, 2013).

Berdasarkan survei serta pengalaman penulis selama menjalani praktik residensi di komunitas, dari sejumlah 72 klien kelolaan yang mengalami penyakit kronis sejumlah 46 klien. Penyakit kronis yang dialami oleh klien diantaranya adalah hipertensi sejumlah 46 klien (100\%), diabetes mellitus sejumlah 4 klien
(9\%), post stroke sejumlah 6 klien (13\%), gagal jantung kongestif sejumlah 2 klien (4\%), dan gagal ginjal kronik sejumlah 1 klien (2\%). Masalah keperawatan fisik dan masalah psikososial ditemukan pada klien yang mengalami penyakit kronis tersebut. Penulis disini hanya berfokus membahas pada masalah keperawatan psikososial saja. Masalah keperawatan psikososial yang dialami oleh klien meliputi ansietas 46 klien (100\%), ketidakberdayaan 36 klien $(78 \%)$, harga diri rendah situasional 36 klien (78\%), gangguan citra tubuh 13 klien $(28 \%)$ dan keputusasaan 2 klien $(4 \%)$. Masalah ketidakberdayaan yang dialami oleh sejumlah 36 klien $(78 \%)$ yang secara keseluruhan ditemukan pada klien dengan penyakit kronis.

Keterbatasan fisik yang banyak dialami oleh klien dengan penyakit kronis mengakibatkan klien menjadi tergantung kepada orang lain untuk melakukan kebutuhan dasarnya. Ketergantungan klien kepada orang lain tersebut seringkali mengakibatkan klien merasa menjadi beban bagi orang lain yang diikuti, hilangnya harapan hidup dan memandang diri dengan rendah. Beberapa klien dengan penyakit kronis pada kondisi yang buruk bahkan mengungkapkan jika lebih baik dirinya mengakhiri hidup daripada harus menjadi beban dan merepotkan orang lain akibat harus mengurus mereka.

Klien yang mengalami penyakit kronis juga menjadi pesimis dengan masa depannya dan merasa tidak berdaya pada saat menerima hal negatif dari lingkungan sekitarnya yang tidak memberikan dukungan pada saat klien mengalami stres akibat penyakit kronis yang dideritanya. Kondisi tersebut mengakibatkan klien memandang dirinya adalah orang tidak 
Berlian Nurtyashesti Kusumadewi, Novy H.C. Daulima, Ice Yulia. W

Efektifitas Terapi Kognitif, Psikoedukasi Keluarga Dan Terapi Kelompok Suportif Pada Klien Dengan Ketidakberdayaan Melalui Pendekatan Model Transisional Meleis

berguna yang akan menuntun kepada kondisi depresi dan gangguan mood.

Beberapa klien yang mengalami penyakit kronis juga membandingkan riwayat penyakit yang dialaminya dengan penyakit yang diderita oleh anggota keluarga yang lain atau orang lain di sekitar mereka. Apabila mereka mengetahui informasi tentang kegagalan dalam suatu pengobatan penyakit biasanya mereka akan menolak pemberian pengobatan yang sama tersebut dan lebih memilih pengobatan yang memiliki riwayat efektif dalam menyembuhkan suatu penyakit.

Hal tersebut menunjukkan jika klien dengan penyakit kronis tidak mengembangkan pemikiran positif, overgeneralisasi terhadap satu hal buruk yang terjadi dan menyimpulkan jika mereka dikelilingi oleh hal-hal yang negatif. Kondisi tersebut akan mengakibatkan depresi pada klien (Bano \& Riaz, 2015).

Keyakinan individu jika setiap hal yang dilakukannya akan menghasilkan sesuatu yang buruk dan penilaian negatif terhadap diri sendiri menjadi penyebab terjadinya depresi. Individu yang kurang mendapat dukungan sosial selama mengalami kejadian yang buruk dalam hidupnya seringkali akan meningkatkan rasa putus asa, tidak berdaya dan depresi (Fortinash \& Worret, 2012). Miranda \& Roman (2013) mengemukakan jika ketidakberdayaan dan gejala depresi menunjukkan hubungan yang signifikan dan positif dengan ide untuk bunuh diri.

Hal-hal tersebut yang membuat penulis tertarik untuk membahas masalah ketidakberdayaan pada klien dengan penyakit kronis yang berada di area komunitas. Penulis juga telah menerapkan berbagai macam psikoterapi selama menjalani praktik. Pada karya ilmiah ini, penulis memfokuskan pada penerapan pemberian terapi kognitif, psikoedukasi keluarga dan terapi kelompok suportif dalam mengatasi masalah keperawatan ketidakberdayaan pada klien dengan penyakit kronis. Pendekatan yang dilakukan dalam mengatasi masalah ini adalah model transisional Meleis.

\section{METODE}

Karya ilmiah ini dilakukan di masyarakat dalam program Community Mental Health nursing (CMHN).

\section{HASIL}

Presentase terbesar rentang usia klien adalah lanjut usia (61-70 tahun) sebesar 55,6\%. Jenis kelamin perempuan merupakan presentase terbanyak yaitu sebanyak 32 orang $(88,9 \%)$. Sebanyak 33 orang klien tidak bekerja $(91,7 \%)$. Presentase terbanyak pendidikan klien adalah tamat SMA yaitu 14 klien $(38,9 \%)$ dan status pernikahan klien yang paling banyak yaitu menikah sebanyak 22 klien $(61,1 \%)$. Pelaku rawat klien dengan ketidakberdayaan paling banyak berusia 51-60 tahun yaitu sebanyak 14 pelaku rawat $(38,9 \%)$ dan berjenis kelamin perempuan sebanyak 19 pelaku rawat $(52,8 \%)$. Pelaku rawat klien sebagian besar bekerja sebagai wiraswasta yaitu sejumlah $17(47,2 \%)$ dan berpendidikan terakhir tamat SMA yaitu sejumlah $29 \quad(80,6 \%)$. Sejumlah 30 pelaku rawat $(83,3 \%)$ berstatus menikah dan paling banyak memiliki hubungan keluarga sebagai anak klien yaitu sejumlah 18 (50\%).

Faktor predisposisi terbanyak pada klien dengan ketidakberdayaan yaitu adanya riwayat menderita 
Berlian Nurtyashesti Kusumadewi, Novy H.C. Daulima, Ice Yulia. W

Efektifitas Terapi Kognitif, Psikoedukasi Keluarga Dan Terapi Kelompok Suportif Pada Klien Dengan Ketidakberdayaan Melalui Pendekatan Model Transisional Meleis

penyakit fisik kronis sebelumnya sebanyak 36 klien (100\%). Sebanyak 24 klien $(66,7 \%)$ berkepribadian tertutup sehingga klien cenderung menyimpan sendiri masalah yang dihadapi dan jarang untuk menceritakan perasaannya kepada orang lain. Klien sebagian besar memiliki status ekonomi yang rendah yaitu sejumlah 29 klien $(80,6 \%)$.

Stresor presipitasi biologis terbanyak pada klien yaitu kondisi fiski akibat penyakit yang diderita sebanyak 36 klien (100\%). Kondisi fisik tersebut meliputi keluhan fisik seperti pusing, tengkuk kaku, mudah lelah, kelemahan anggota gerak, nyeri sendi dan adanya ulkus diabetikum. Stresor tersebut dialami oleh klien kurang dari 6 bulan.

Faktor presipitasi psikologis pada klien semuanya bersumber dari internal klien (100\%). Hal tersebut disebabkan karena klien belum mampu menerima adanya perubahan bentuk/fungsi/struktur tubuh akibat penyakit fisik kronis yang diderita. Keterbatasan dalam melakukan aktifitas sehari-hari merupakan stresor sosiokultural yang dialami oleh klien. Stresor tersebut sudah dialami klien kurang dari 6 bulan dan bersumber dari internal klien. Seluruh klien $(100 \%)$ mengalami lebih dari 2 stresor.

Pada aspek kognitif, semua klien dengan masalah ketidakberdayaan $(100 \%)$ mengungkapkan ketidakpastian tentang perubahan energi, mengungkapkan keraguan terhadap penampilan peran dan mengungkapkan bahwa tidak punya kendali atau pengaruh. Perasaan khawatir dialami oleh semua klien dengan masalah ketidakberdayaan tersebut (100\%). Sebanyak 28 klien $(77,8 \%)$ mengungkapkan jika merasakan dada berdebar sebagai bentuk respon fisiologis dari ketidakberdayaan yang dialami.

Semua klien dengan masalah ketidakberdayaan mengungkapkan jika dirinya menjadi tergantung dengan orang lain dan sebanyak 24 klien $(66,7 \%)$ mengemukakan jika dirinya jadi menarik diri dari lingkungan sekitar maupun kegiatan sosial kemasyarakatan. Sebanyak 21 klien dengan masalah ketidakberdayaan $(58,3 \%)$ telah mempunyai kemampuan untuk mengidentifikasi situasi kehidupan yang tidak mampu dikontrol oleh klien. Kemampuan untuk mengidentifikasi pikiran negatif yang muncul telah dimiliki oleh 13 klien $(36,1 \%)$.

Semua pelaku rawat dari klien (100\%) mampu mendiskusikan masalah yang dialami selama merawat klien dengan masalah ketidakberdayaan. Pelayanan kesehatan (puskesmas/RS/klinik dokter praktik) terjangkau aksesnya oleh semua klien dengan masalah ketidakberdayaan (100\%). Sebanyak 31 klien dengan masalah ketidakberdayaan $(86,1 \%)$ memiliki keyakinan untuk sembuh dan percaya dengan pelayanan kesehatan yang ada. Semua klien $(100 \%)$ yang mengalami ketidakberdayaan menggunakan mekanisme koping berdoa/sholat/dzikir sebagai suatu cara untuk mengatasi masalah ketidakberdayaan yang dialami.

Pada saat pelaksanaan terapi kognitf penulis harus melatih ulang penggunaan tanggapan rasional terhadap pikiran negatif yang pertama dan yang kedua kepada sebanyak 22 klien (61,1\%). Hal tersebut dikarenakan klien yang sudah lanjut usia lupa cara untuk melawan pikiran 
Berlian Nurtyashesti Kusumadewi, Novy H.C. Daulima, Ice Yulia. W

Efektifitas Terapi Kognitif, Psikoedukasi Keluarga Dan Terapi Kelompok Suportif Pada Klien Dengan Ketidakberdayaan Melalui Pendekatan Model Transisional Meleis

otomatis negatif sehingga klien harus mengulang kembali cara untuk melawan pikiran otomatis negatif tersebut.

Hasil dari pemberian tindakan keperawatan ners kepada 36 klien dengan masalah ketidakberdayaan berdampak pada penurunan tanda gejala yang dialami oleh klien. Pada aspek kognitif, sebanyak 8 klien $(22,2 \%)$ tidak lagi mengungkapkan ketidakpastian tentang perubahan energi. Sebanyak 6 orang klien $(16,6 \%)$ mengemukakan tidak lagi mengalami rasa takut. Kondisi sulit tidur sudah tidak lagi dialami oleh 8 orang klien $(22,2 \%)$. Klien sejumlah 6 orang $(16,7 \%)$ mengemukakan jika sudah tidak lagi tergantung pada orang lain dan tidak lagi menarik diri dari lingkungan sekitar maupun kegiatan sosial kemasyarakatan.

Pemberian

keperawatan Ners ditambah pemberian tindakan keperawatan spesialis berupa terapi kognitif dan psikoedukasi keluarga menurunkan tanda gejala yang dialami oleh klien. Pada aspek kognitif, sejumlah 16 klien $(100 \%)$ yang telah mendapat tindakan keperawatan Ners masih mengungkapkan tentang ketidakpastian tentang perubahan energi, keraguan terhadap penampilan peran dan tidak punya kendali atau pengaruh. Setelah dilakukan pemberian tindakan keperawatan spesialis berupa terapi kognitif dan psikoedukasi keluarga, tinggal 8 klien $(50 \%)$ yang masih mengungkapkan tentang ketidakpastian tentang perubahan energi, keraguan terhadap penampilan peran dan tidak punya kendali atau pengaruh.

Sejumlah 13 klien $(81,3 \%)$ masih merasa tertekan dan 11 klien khawatir $(68,8 \%)$ setelah pemberian tindakan keperawatan Ners. Didapatkan hasil setelah kemudian dilakukan pemberian terapi kognitif dan psikoedukasi keluarga bahwa tinggal 4 klien (25\%) yang masih merasa tertekan dan 2 klien (12,5\%) yang merasa khawatir. Pada aspek fisiologis, sebanyak 5 klien $(31,3 \%)$ masih mengalami perubahan denyut jantung dan dada yang berdebar setelah dilakukan pemberian tindakan keperawatan Ners.

Pemberian tambahan terapi kognitif dan psikoedukasi keluarga menunjukkan hasil hanya tinggal 1 klien $(6,3 \%)$ yang mengalami perubahan denyut jantung dan dada yang berdebar. Sebanyak 10 klien $(62,5 \%)$ masih menunjukkan perilaku tergantung dengan orang lain setelah dilakukan pemberian tindakan keperawatan Ners.

Pemberian tambahan terapi kognitif dan psikoedukasi keluarga menunjukkan hasil bahwa tinggal 5 klien $(31,3 \%)$ yang menunjukkan perilaku tergantung dengan orang lain. Disisi lain, 5 klien (31,3\%) yang telah mendapatkan tindakan keperawatan Ners, terapi kognitif dan psikoedukasi keluarga masih menunjukkan perilaku pasif, acuh terhadap kondisi kesehatan dan tidak memantau kemajuan pengobatan.

Sejumlah 8 klien (50\%) yang menarik diri dari lingkungan sekitar maupun kegiatan sosial kemasyarakatan walaupun telah dilakukan pemberian tindakan keperawatan Ners menunjukkan perubahan setelah dilakukan tambahan terapi kognitif dan psikoedukasi keluarga menjadi tinggal 3 klien $(18,8 \%)$ yang masih menarik diri dari lingkungan sekitar.

Pada pemberian tindakan keperawatan Ners, sejumlah 36 klien 
Berlian Nurtyashesti Kusumadewi, Novy H.C. Daulima, Ice Yulia. W

Efektifitas Terapi Kognitif, Psikoedukasi Keluarga Dan Terapi Kelompok Suportif Pada Klien Dengan Ketidakberdayaan Melalui Pendekatan Model Transisional Meleis

yang pada awalnya tidak ada yang mampu $(0 \%)$ untuk mengendalikan situasi yang masih bisa dilakukan bertambah menjadi mampu mengendalikan situasi yang masih bisa dilakukan yaitu sebanyak 29 klien $(80,6 \%)$. Klien yang pada awalnya tidak mempunyai kemampuan $(0 \%)$ untuk mengidentifikasi pikiran otomatis negatif dan penggunaan tanggapan rasional terhadap pikiran negatif yang muncul dan mengungkapkan manfaat tanggapan rasional terhadap pikiran otomatis negatif menjadi mampu untuk melakukan hal tersebut setelah pemberian terapi kognitif yaitu sebanyak 31 klien $(86,1 \%)$.

Kemampuan dalam menggunakan sistem pendukung juga meningkat, klien yang pada awalnya tidak memiliki kemampuan $(0 \%)$ untuk menggunakan sistem pendukung dalam keluarga, menggunakan sistem pendukung diluar keluarga dan mengevaluasi hasil dan hambatan penggunaan sistem pendukung. Setelah klien mendapat pemberian terapi suportif, sebanyak 20 klien (100\%) menjadi mampu untuk menggunakan sistem pendukung yang ada.

Kemampuan keluarga sebagai pelaku rawat klien dengan ketidakberdayaan meningkat setelah pemberian tindakan keperawatan Ners dan spesialis. Sejumlah 36 keluarga $(100 \%)$ setelah pemberian tindakan keperawatan spesialis menjadi mampu untuk melatih cara mengontrol rasa tidak berdaya dengan melatih klien berkegiatan sesuai kondisi dan menjelaskan waktu untuk kontrol atau rujukan. Setelah pemberian psikoedukasi keluarga, sejumlah 36 keluarga (100\%) menjadi mempunyai kemampuan untuk memanajemen stres, memanajemen beban dan melakukan pemberdayaan komunitas.

\section{PEMBAHASAN}

Miranda \& Roman (2013) mengungkapkan jika umur, jenis kelamin, ras/etnis individu dan tempat kelahiran tidak secara signifikan menjadi penyebab ketidakberdayaan individu. Identitas diri individu sebagai bagian dari etnis tertentu tidak berhubungan dengan ketidakberdayaan, gejala depresi dan ide untuk bunh diri. Koping yang digunakan oleh klien dengan penyakit kronis juga tidak selalu bersifat maladaptif. Penelitian yang dilakukan di Pakistan menunjukkan bahwa klien yang didiagnosis menderit penyakit kronis dan berada dalam situasi yang penuh dengan tekanan masih mampu untu menggunakan koping maladaptif dalam hal keagamaan dan mengubah sudut pandangnya dalam melihat dan mengatasi stres yang dialami. Klien dengan penyakit kronis di Pakistan memaknai penyakit yang diderita sebagai suatu hal yang wajib untuk dijalani, bisa jadi penyakit tersebut sebagai penghapus dosa kepada Tuhan (Bano \& Riaz, 2015).

Terapi kognitif telah dibuktikan dengan penelitian bahwa berpengaruh menurunkan respon ketidakberdayaan pada klien stroke (Ramadia, Keliat dan Wardhani, 2013). Klien usia dewasa yang mengalami depresi menunjukkan kemajuan yang lebih baik dalam hal penurunan gejala depresi setelah dilakukan pemberian terapi kognitif dibandingkan dengan psikoterapi individu lain yang diberikan untuk klien dewasa yang mengalami depresi (Arntz, DeRubeis, Huibers, Lemmens Dan Peeters, 2015).

Terapi kognitif yang diberikan pada klien dengan gangguan bipolar 
Berlian Nurtyashesti Kusumadewi, Novy H.C. Daulima, Ice Yulia. W

Efektifitas Terapi Kognitif, Psikoedukasi Keluarga Dan Terapi Kelompok Suportif Pada Klien Dengan Ketidakberdayaan Melalui Pendekatan Model Transisional Meleis

juga menunjukkan jika terapi kognitif lebih efektif dalam mengatasi ketidakberdayaan yang dialami oleh klien dibandingkan dengan pemberian terapi suportif Rogerian (Bonasee et $a l$, 2009). Kondisi ketidakberdayaan yang dialami oleh klien lebih tinggi pada kelompok yang tidak menunjukkan kemajuan pada awal pemberian terapi kognitif. Klien yang berespons terhadap pemberian terapi kognitif lebih sedikit yang pada akhirnya mengarah kepada kondisi depresi dibandingkan dengan kelompok yang tidak berespons terhadap pemberian terapi kognitif. Klien yang berespons terhadap pemberian terapi kognitif jika mengalami kondisi depresi menunjukkan tingkat keparahan dalam hal gejala yang dialami dibandingkan dengan klien yang tidak menunjukkan kemajuan pada awal pemberian terapi kognitif (Kuyken, 2004).

Chan, Chan \& Leow (2015) mengemukakan jika pemberian psikoedukasi pada keluarga sebagai pelaku rawat klien kanker menunjukkan beberapa hal yaitu: hasil terhadap kualitas hidup yang lebih baik pada pelaku rawat, pemberian dukungan sosial yang lebih baik kepada klien, jumlah anggota keluarga bertambah menjad lebih banyak dalam memberikan dukungan kepada klien, pelaku rawat menjadi lebih dekat dengan klien, berpengaruh terhadap efikasi diri klien dalam kemampuan merawat diri sendiri, pelaku rawat merasa lebih dihargai, menambah pengetahuan pelaku rawat, dan mengurangi kondisi stres serta depresi yang dialami oleh pelaku rawat.

Terapi kelompok merupakan terapi yang ideal bagi klien dengan penyakit kornis. Hal tersebut dikarenakan terapi kelompok dapat dianggap sebagai harapan, komunitas terbuka, sarana sumber informasi, sarana peningkatan harga diri, pengembangan lingkungan dan dukungan sosial, sumber pembelajaran mekanisme koping berdasarkan pengalaman orang lain, wahana mengekspresikan emosi dan perasaan serta menjadi tempat pembelajaran terhadap kemungkinan terjadinya kejadian yang baik maupun buruk di kemudian hari (Varcarolis dan Halter, 20120).

Penelitian menunjukkan setelah dilakukan terapi kelompok suportif ketidakberdayaan yang dialami oleh klien dengan kanker payudara mengalami penurunan. Klien juga mengalami peningkatan kemampuan untuk membangun komunikasi yang terbuka dengan keluarga tentang kondisi penyakit yang diderita (Biancosino, Grassi, Marmai, Rossi dan Sabato, 2009). Hasil penelitian Lestari, Daulima dan Astari (2013) juga menyatakan jika terapi kelompok suportif dapat menurunkan respon ketidakberdayaan pada klien dengan kanker.

\section{KESIMPULAN}

Rentang usia klien dengan masalah ketidakberdayaan paling banyak adalah lanjut usia, berjenis kelamin perempuan, tidak bekerja, berpendidikan tamat SMA dan telah menikah. Pelaku rawat klien dengan masalah ketidakberdayaan paling banyak berusia dewasa akhir, berjenis kelamin perempuan, bekerja sebagai wiraswasta dan berpendidikan terakhir tamat SMA. Semua pelaku rawat berstatus menikah dan paling banyak memiliki hubungan keluarga sebagai anak klien. Faktor predisposisi terbanyak pada klien dengan ketidakberdayaan yaitu adanya 
Berlian Nurtyashesti Kusumadewi, Novy H.C. Daulima, Ice Yulia. W

Efektifitas Terapi Kognitif, Psikoedukasi Keluarga Dan Terapi Kelompok Suportif Pada Klien Dengan Ketidakberdayaan Melalui Pendekatan Model Transisional Meleis

riwayat menderita penyakit fisik kronis sebelumnya, berkepribadian tertutup dan sebagian besar memiliki status ekonomi yang rendah.

Stresor presipitasi biologis terbanyak pada klien yaitu kondisi fisik akibat penyakit yang diderita Kondisi fisik tersebut meliputi keluhan fisik seperti pusing, tengkuk kaku, mudah lelah, kelemahan anggota gerak, nyeri sendi dan adanya ulkus diabetikum. Stresor tersebut dialami oleh klien kurang dari 6 bulan. Faktor presipitasi psikologis pada klien semuanya bersumber dari internal klien. Hal tersebut disebabkan karena klien belum mampu menerima adanya perubahan bentuk/fungsi/struktur tubuh akibat penyakit fisik kronis yang diderita. Keterbatasan dalam melakukan aktifitas sehari-hari merupakan stresor sosiokultural yang dialami oleh klien. Stresor tersebut sudah dialami klien kurang dari 6 bulan dan bersumber dari internal klien. Seluruh klien mengalami lebih dari 2 stresor.

Semua klien dengan masalah ketidakberdayaan mengungkapkan ketidakpastian tentang perubahan energi, mengungkapkan keraguan terhadap penampilan peran dan mengungkapkan bahwa tidak punya kendali atau pengaruh. Perasaan khawatir dialami oleh semua klien dengan masalah ketidakberdayaan. Sebagian besar klien mengungkapkan jika merasakan dada berdebar sebagai bentuk respon fisiologis dari ketidakberdayaan yang dialami. Semua klien dengan masalah ketidakberdayaan mengungkapkan jika dirinya menjadi tergantung dengan orang lain dan menarik diri dari lingkungan sekitar maupun kegiatan sosial kemasyarakatan.
Jumlah klien ketidakberdayaan yang mengalami penurunan tanda gejala lebih banyak pada klien yang mendapat paket tindakan keperawatan generalis, terapi kognitif, psikoedukasi keluarga dan terapi suportif dibandingkan dengan klien yang hanya mendapat paket tindakan keperawatan generalis saja maupun klien yang mendapat pemberian tindakan keperawatan generalis, terapi kognitif dan psikoedukasi keluarga. Kemampuan klien mengalami peningkatan setelah mendapatkan paket tindakan keperawatan generalis, terapi kognitif dan terapi suportif. Kemampuan pelaku rawat mengalami peningkatan setelah mendapatkan tindakan keperawatan generalis untuk keluarga dan psikoedukasi keluarga.

\section{DAFTAR PUSTAKA}

Arntz, A., DeRubeis, RJ., Huibers, MJH., Lemmens, LHJM., Peeters, FPML. (2015). Sudden Gains In Cognitive Therapy And Interpersonal Psychoterapy For Adult Depression. Behaviour Research And Therapy 77: 170-176.

Balbag, Z., Cemrek, F., Mutlu, T. (2010). The Role Of Self Esteem, Locus Of Control And Big Five Personality Traits In Predicting Hopelessness. Procedia Social And Behavioral Sciences 9: 17881792.

Bano, N., Riaz, Z. (2015). Self Esteem

As A Determinant Of Depression In Women With Chronic Illness. Pakistan Journal of Clinical Psychology 14: 53-66.

Biancosino, B., Grassi, L., Marmai, L., Rossi, E., Sabato, S. (2009). 
Berlian Nurtyashesti Kusumadewi, Novy H.C. Daulima, Ice Yulia. W

Efektifitas Terapi Kognitif, Psikoedukasi Keluarga Dan Terapi Kelompok Suportif Pada Klien Dengan Ketidakberdayaan Melalui Pendekatan Model Transisional Meleis

Effects Of Supportive

Expressive Group Therapy In

Breast Cancer Patients With

Affective Disorders: A Pilot

Study. Psychotherapy And

Psychosomatics 79: 39-47.

Bonasee, $F$ et al. (2009). Cognitive

Therapy Versus Rogerian

Supportive Therapy In

Borderline Personality

Disorder. Psychoterapy And

Psychosomatics 78: 307-316.

Boyd, M. A. (2012). Psychiatric

nursing: Contamporary

practice (5th ed.).

Philadelphia: Lippincot

William \& Wilkins.

Chan, MF., Chan, S., Leow, M. (2015). A Pilot Randomized, Controlled Trial Of The Effectiveness of A Psychoeducational

Intervention On Family Caregivers Of Patients With Advanced Cancer. Oncology Nursing Forum Vol. 42, No. 2: 63-72.

DeRubeis, RJ., German, RE., Luaces, LL. (2015). It's Complicated: The Relation Between Cognitive Change Procedures, Cognitive Change, And Symptom Change In Cognitive Therapy For Depression. Clinical Psychology Review 41: 3-15.

Miranda, R., Roman, L.P. (2013). Culturally Related Stress, Hopelessness, and Vulnerability to Depressive Symptoms and Suicidal Ideation In Emerging Adulthood. Journal Of Behaviour Therapy 44: 75-87.

Wang, L et al. (2013). Cognitive Trio: Realtionship With Major Depression And Clinical
Predictors In Han Chinese Women.Psychological Medicine 43: 2265-2275.

Fields, SA., Hale, LR. (2011). Psychoeducational Groups For Youth Attention Deficit Hyperactivity Disorder: A Family Medicine Pilot Project. Mental Health In Family Medicine 8: 157-165. 